\title{
Characterization and Synthesis through Fast Phase-Transfer of Oil-Soluble Double-Coordinated Tea-Polyphenols Arsenic
}

\author{
Wenfu Zhou, Yahong Chen, Lin Zhang \\ College of Chemistry and Biological Engineering, Sanming University, Sanming, China \\ Email: smiling97@sina.com
}

Received 25 May 2014; revised 10 July 2014; accepted 23 July 2014

Copyright (C) 2014 by authors and Scientific Research Publishing Inc. This work is licensed under the Creative Commons Attribution International License (CC BY). http://creativecommons.org/licenses/by/4.0/

(c) (i) Open Access

\begin{abstract}
Fast phase-transferring was adopted in ethanol solution at the condition of $\mathbf{n}$ (oil-soluble tea polyphenol): $\mathrm{N}\left(\mathrm{As}^{3+}\right)=2: 1,4: 1,6: 1, \mathrm{pH}=4.0$, temperature $40^{\circ} \mathrm{C}-45^{\circ} \mathrm{C}$, action period of $15 \mathrm{~h}$ to compose the target, of which the productivity was $59 \%$, UV was $267.50,218.00,220.50 \mathrm{~nm}$, FTIR was $6291,34158.6,2850.2,1708.2 ; 1457.3 ; 1370.4,1224.2,1144.0,760.5 \mathrm{~cm}^{-1}$, fluorescence value $\lambda_{\max }$ $=257,591.1,593.7,590.3,591.0,591.5, \mathrm{XRD} \lambda / \mathrm{nm}$ is $3.6974,4.186,12.0762,15.4747,1 \mathrm{H}-\mathrm{NMR} \delta=$ $0.782,1.193,1.483$ - 1.586, 1.959 - 2.184, 2.479, 3.116, 3.970 - 3.981, 5.231 - 5.753, 6.537 - 7.300 . Finally it was ascertained through XRD as double-coordinated polycrystal compound.
\end{abstract}

\section{Keywords}

Oil-Soluble, Tea-Polyphenols (TP), Arsenic Compound, Fast Phase-Transfer, Synthesis, Characterization

\section{Introduction}

Tea polyphenols (TP) is a group of poly-hydroxyl compounds existing in tea leaves, which is capable of antioxidation, anti-mutation, anti-inflammation, anti-virus and so on [1]-[4]. TP are newly found absolute natural antioxidant and green medicine for anticancer while arsenic is a poisonous element. Lots of experiments have proved that arsenic of small dosage acts as activating enzyme-interact with sulfhydryl group of oxidating enzyme in organism improving assimilation and abating dissimilation [5]-[14]. What's more, it has been proved by the document that trivalent arsenic tends to combine with cysteine to produce a certain catalyst for oxidation far 
more active than pure cysteine [12]-[16]. Arsenic trioxide is also highly toxic. It destroys respiratory enzyme of some cells after entering into human body and kills people by isolating tissue from oxygen. Strongly irritating to stomach mucosa, arsenic trioxide also festers mucosa of stomach and intestine. Blood vessels and liver will also be damaged and in serious condition human will die of paralysis of respiratory and central nervous system in one hour. Project Team of Class 2006 led by Zhou Wenfu has successfully synthesized oil-soluble tea-polyphenols arsenic (OTP-As) and proved its pharmaceutical effect with lightly toxicity by experimenting on rats [17], which also indicates that the toxicity of OTP-As is catabolized in two weeks; but its application was much restricted due to insolubility in oil and water. We made TP react with fatty acyl chloride to produce TP fatty acid ester to enhance its ability of dissolving in oil and then the oil-soluble TP was complexed with arsenic ion to produce OTP-As [10]. The compound may replace highly poisonous pure arsenic trioxide and be applied to treat leukemia and control intestinal parasite; but we did not do further experiment to confirm it. Nothing on similar topics is reported in international and Chinese periodicals literature.

\section{Experiments}

\subsection{Materials and Instruments}

Materials: tea contain 95\% TP (ecological tea from West Lake in Nanchang) Sixteen chloride (AR), ethyl acetate (AR), three arsenic chloride (AR), hydrochloric acid (AR), ethanol (AR) sodium hydroxide (CP), sodium carbonate solid (CP). Instrument: UV-Vis spectrophotometer UV-1100 (Beijing Rayleigh Analytical Instrument Company), Fourier Thermo infrared spectrometer FT-IR 360 (American Nicolet company), NMR Unity-500 (American Vavian Company) XRD diffraction, Rigaku DMax-2500 X-RAY Diffracto meter: D/MAX-III A automatic, pipe flow, pressure $40 \mathrm{KV}, 100 \mathrm{~mA}, \lambda=0.154 \mathrm{~nm}$ starting angle is 5 degrees, the end angle $65^{\circ}$, step $2 \mathrm{~nm}$, scanning speed 12/min, the integral time 1/s, target type Cu, Filter Sm (RIGAKU), fluorescence spectrophotometer 970 CRT (Analytic Instrument City in Shanghai), Visible spectrophotometer 722 S (Shanghai Precise Scientific Instrument Co. Ltd.), circulating water pumps (Zhengzhou Du Fu instrument factory), vacuum drying box 2K-82B (Shanghai Experimental Instrument General Factory), and the thermostat magnetic stirrer, electric jacket and other commonly used instruments.

\subsection{Synthesis of OTP [18]-[20]}

$5 \mathrm{~g}$ tea polyphenols (TP) was dissolved in ethyl acetate, to which $12.5 \mathrm{ml}$ sixteen chloride (SC) was added at $\mathrm{n}$ (TP):n (SC) $=1: 3$. Solid sodium hydroxide was added to adjust the $\mathrm{pH}$ value to $4.8-5.1$. The mixture was stirred at $40^{\circ} \mathrm{C}$ to get Brown turbid solution. Warm water was used to wash the solution many times until it was neutral, red brown solution. And ethyl acetate was distilled to generate red brown viscous liquid, which was dried at $40^{\circ} \mathrm{C}$ to produce $12.8982 \mathrm{~g}$ light yellow powder. The productivity is $96.89 \%$.

\subsection{Synthesis of OTP-As}

OTP and $\mathrm{As}^{3+}$ were dissolved in $50 \mathrm{~mL}$ ethanol at $\mathrm{n}(\mathrm{OTP}): \mathrm{n}\left(\mathrm{As}^{3+}\right)=2: 1,4: 1,6: 1$ and saturate sodium carbonate solution was added to adjust $\mathrm{pH}$ to a certain value. Then the solution was stirred for 15 hours at $40^{\circ} \mathrm{C}-45^{\circ} \mathrm{C}$, turning from red to brown and to bright red and then brown, producing a large amount of dark brown precipitate, which was filtrated in vacuum filtration, cleansed and purified, and dried in vacuum. We got light brown solid powder $7.3962 \mathrm{~g}, 7.4306 \mathrm{~g}$ and $7.4537 \mathrm{~g}$. The yield did not differ much for an average of 59\%.

\section{Results and Discussion}

\subsection{Choice of Catalyst}

Alkali acts as catalyst in acyl chloride esterification. Anhydrous sodium carbonate, solid sodium hydroxide and amine were used as catalyst in the synthesis of OTP. The results are shown in Table 1.

\subsection{Structural Characterization}

\subsubsection{UV Spectral Analysis}

UV-Vis absorption spectroscopy performs qualitative and quantitative analysis and structural characterization through studying the absorption by molecules or ions of radiant energy in the UV and visible spectrum region. It 
reflects the transition between the energy level of electrons in molecules. Molar ratio is $\mathrm{n}(\mathrm{OTP}): \mathrm{n}\left(\mathrm{As}^{3+}\right)=2: 1$ (Figure 1), 4:1 (Figure 2), 6:1 (Figure 3).

UV-Vis spectrum detects changes of peak in conjugated system. Coordination numbers changes after the complexing of OTP and OTP-As while conjugation system remains the same. In this way UV-Vis spectrum

Table 1. Catalyst choices.

\begin{tabular}{cccc}
\hline Catalyst & Anhydrous sodium carbonate & Sodium hydroxide(s) & Amine (AR) \\
Phenomena & $\begin{array}{l}\text { Turned from red brown to brown after } \\
\text { TP was added, not muddy }\end{array}$ & $\begin{array}{l}\text { Became muddy some time later after } \\
\text { TP was added and kept muddy when } \\
\text { it was over }\end{array}$ & $\begin{array}{l}\text { Became muddy right after TP was } \\
\text { added and sticky substance } \\
\text { appeared }\end{array}$ \\
Color & Dark orange & Light soil-yellow & Dark brown \\
Stir period $(\mathrm{h})$ & $8 \mathrm{~h}$ & $8 \mathrm{~h}$ & $8 \mathrm{~h}$ \\
\hline
\end{tabular}

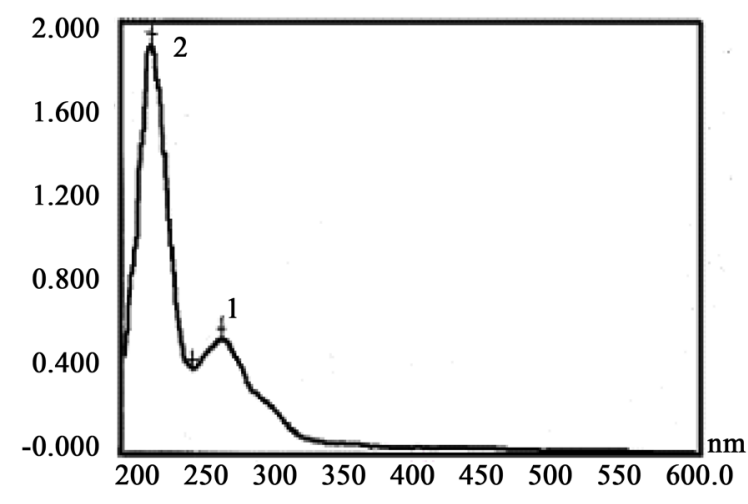

Figure 1. UV spectrum of OTP-As (2:1).

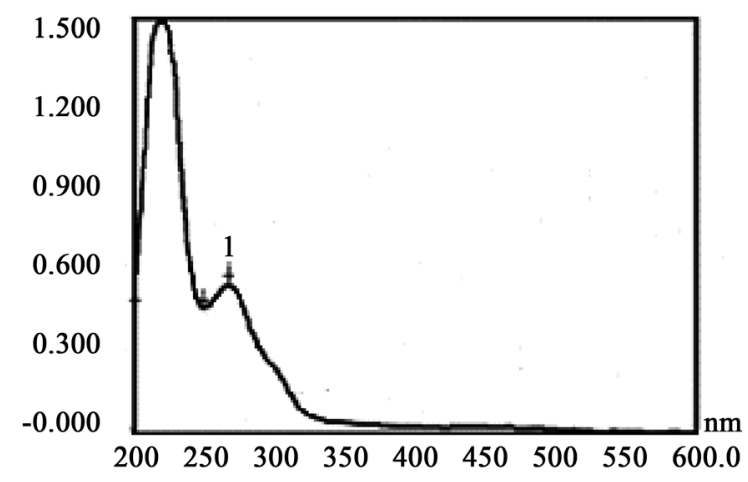

Figure 2. UV spectrum of OTP-As (4:1).

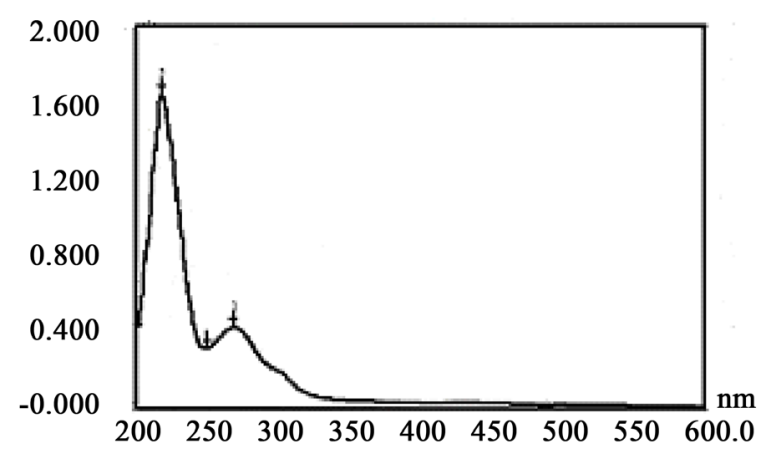

Figure 3. UV spectrum of OTP-As (6:1). 
strongly proofs the number of moles of OTP has little influence on coordination structure of arsenic ion.

Figure 1, Figure 2 and Figure 3 shows that UV-vis absorption peak of OTP-As is not affected by different ratio of $\mathrm{n}(\mathrm{OTP})$ to $\mathrm{n}\left(\mathrm{As}^{3+}\right)$, the maximum value of which is in the vicinity of $267.50 \mathrm{~nm}$ and $220 \mathrm{~nm}$ shown in Table 2. Comparing three UV graphs, the maximum absorption peak wavelength is almost the same, which shows that the conjugated system is similar; it means the number of moles of OTP has little influence on coordination structure of arsenic ion and all of the complex is double-coordinated.

\subsubsection{FTIR Spectral Analysis}

Infrared spectroscopy identifies compounds and determines molecular structure through collecting information about atomic relative vibration and molecular vibration information. FTIR spectrum of Figure 4. OTP-As of which the molar ratio is $\mathrm{n}(\mathrm{OTP}): \mathrm{n}\left(\mathrm{As}^{3+}\right)=2: 1$. FTIR spectrum of Figure 5. OTP-As of three kinds of different molar ratio of $n(\mathrm{OTP}): \mathrm{n}\left(\mathrm{As}^{3+}\right)=2: 1,4: 1,6: 1$ as shown in.

The molecular vibration frequency is proportional to the group binding constant $\mathrm{K} 1 / 2$, so when the binding force constant reduces, $\lambda$ value approximates lower wave number. Figure 5 shows that the infrared feature information isomers are almost the same. Although OTP-As is a mixture, they have the same functional group and the structure is similar. Different ratio of $n\left(\right.$ OTP):n $\left(\mathrm{As}^{3+}\right)$ does not exert much influence on infrared characteristic absorption peak of OTP-As. The structural information of the FTIR spectrum Figure 5 is consistent with that of UV spectrum.

\begin{tabular}{cccc} 
Table 2. UV values of OTP-As. & & & \\
\hline $\mathrm{n}(\mathrm{OTP}): \mathrm{n}\left(\mathrm{As}^{3+}\right)$ & $2: 1$ & $4: 1$ & $6: 1$ \\
Peak wavelength (nm) & $267.50,218.00$ & $267.50,220.50$ & $267.50,220.00$ \\
Peak value & $0.418,1.635$ & $0.531,1.496$ & $0.527,1.892$ \\
\hline
\end{tabular}

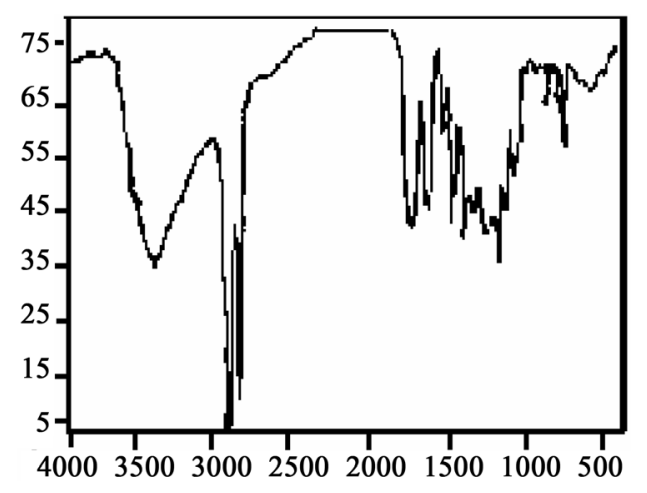

Figure 4. FTIR spectrum of OTP-As (2:1).

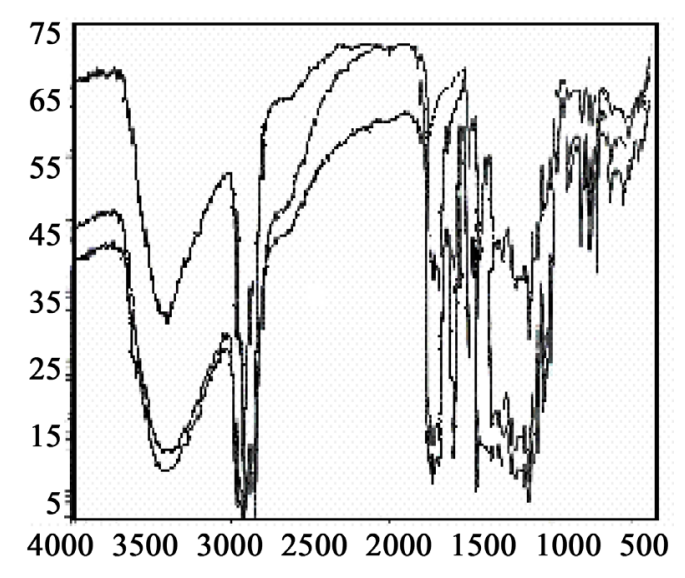

Figure 5. FTIR spectrum of OTP-As (2:1, 4:1, 6:1). 


\subsubsection{Fluorescence Spectrometry Analysis [21]}

Molecular fluorescence analysis is a quantitative method based on fluorescence intensity of material. The complexes determined by this experiment were $\mathrm{A}=(\mathrm{EGC})_{2} \mathrm{As}$ or $(\mathrm{ECG})_{2} \mathrm{As}, \mathrm{B}=(\mathrm{EGCG})_{2} \mathrm{As}, \mathrm{C}=(\mathrm{EC})_{2} \mathrm{As}$ [the molar ratio $\left.\mathrm{n}(\mathrm{OTP}): \mathrm{n}\left(\mathrm{As}^{3+}\right)=2: 1,4: 1,6: 1\right]$. Experiment results show that $\lambda$ value in fluorescence spectrum of OTP-As of different complexes with different concentrations is similar but the fluorescence intensity is different (Figure 6, Figure 7). We can see that EX wavelength is about $257.0 \mathrm{~nm}$ when OTP-As complexes are in excited state while EM wavelength is about 591.1 - $593.7 .0 \mathrm{~nm}$ when they are in launching state. The higher the concentration of the solution is, the stronger INT intensity is. Because of the dilute concentration, when excited light intensity is constant, fluorescence intensity is proportional to the concentration of fluorescent matter- $\mathrm{F}=$ $\mathrm{K} \times \mathrm{C}$ [13]. Analyze Figure 7 we can see that maximum peak of EM graph often complex was at wavelength $\lambda$ $=591.0 \mathrm{~nm}$; and the higher concentration of the solution is, the stronger the intensity of EM is.

Figure 7 shows that EX spectrum (excited) $\lambda 200$ - $400 \mathrm{~nm}$ of OTP-As complexes of the same proportion are almost the same, the maximum peak wavelength $\lambda$ nearly overlap; but their EM spectra (emission) intensity of $500-650 \mathrm{~nm}$ differentiates significantly. The increasing of the molecular conjugated structure system and the molecular plane rigidity reduce the molecular vibration, along with the interaction between the molecule and the solvent or other solute molecules, meaning external transfer loss of molecular energy in excited state reduces and favors fluorescence emission. And the increase of rigid plane can enlarge the absorption cross section of molecules, molar absorption coefficient, and fluorescence intensity. Because the larger the non-local area of $\pi$ electron is, the easier it is to be excited; and molecular fluorescence efficiency will also enhances. In addition, electron-donating groups such as - $\mathrm{OH}$, -OR increase the transition probability between the lowest excited singlet and ground state; and often intensify the fluorescence, $\lambda$ moves to long wavelength side. Compare A, B, C curve in Figure 7, the wavelength corresponding to their maximum peak is slightly different; B curve stands for (EGCG) $)_{2}$ As, of which the maximum peak wavelength is $593.7 \mathrm{~nm}$. Conjugation degree increases because of a lot of free phenol -OH. And since molecular weight of the complex was large, solubility low, concentration low, EM intensity was low. But the wavelength corresponding to the maximum peak of $\mathrm{A}$, $\mathrm{C}$ curve were the same, and EM intensity of Curve A is obviously weaker than that of Curve C. Presumably it stands for (EGC) ${ }_{2} \mathrm{As}$ or $(\text { ECG })_{2}$ As. Because free phenol -OH in molecules reduced, fluorescence $\lambda$ became a bit smaller as $591.1 \mathrm{~nm}$,

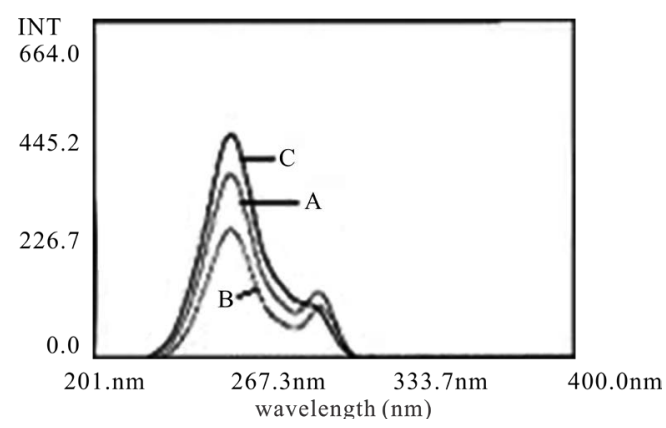

Figure 6. EX (200 - $400 \mathrm{~nm})$, EM (500 - $650 \mathrm{~nm}$ ) spectrm of OTP-As complex of different concentration, different proportion.
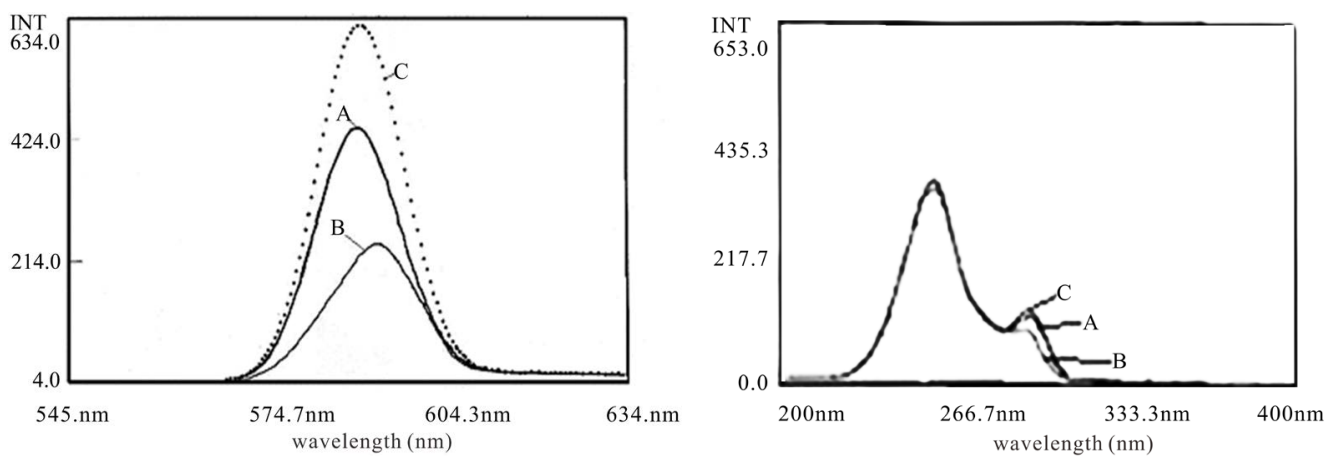

Figure 7. EX (200 - $400 \mathrm{~nm})$, EM (500 - 650nm) spectrum of OTP-As of the same proportion, different concentration. 
the solubility of the molecules is slightly enhanced; and solution concentration is quite high; the EM intensity was stronger than that of Curve B. Curve C stands for (EC) ${ }_{2} \mathrm{As}$, fluorescence $\lambda$ is $590.3 \mathrm{~nm}$, minimum molecular weight, high solubility and high concentration, all of which led to great EM intensity. In Table 3, EM spectrum revealed information about 5 kinds of OTP-As mixture generating different complex. [note] A, B, C respectively stand for 2:1, 4:1, 6:1 OTP-As dissolved in $60 \mathrm{~mL} 95 \%$ ethanol solution.

\subsubsection{X-Ray Diffraction [11] [17]}

$\mathrm{X}$ ray is a kind of electromagnetic radiation generated by electron beam bombarding elements in the $\mathrm{X}$ ray tube. $\mathrm{X}$-ray diffraction is an effective means of analyzing crystal structure for diffraction peak intensity and half peak width reflects amorphous degree of powder and changing information of lattice. In Table 4, $2 \theta$ stands for diffraction, D crystal grain size, B half peak width. Figure 8 is XRD for OTP-As.

According to test data in Figure 8, diffraction peak of $\lambda / \mathrm{nm}=21.401$ is the strongest, which shows OTP-As is polycrystal mixture. Information provided by Figure 8 XRD indicates that OTP-As is mixture.

\subsubsection{Spectrophotometry}

Basing on substance's selective absorption of light, Spectrophotometric analysis method can not only determine most inorganic ions but many organic compounds. It can not only be used as quantitative analysis but also qualitative analysis for some organic compounds and determination of physical and chemical constant as well as the composition of complex. Table 5 shows photometric value of OTP-As of different mass dissolved in $60 \mathrm{~mL} 95 \%$

Table 3. Numbers of value of fluorescence of OTP-As.

\begin{tabular}{cccc}
\hline & A & B & C \\
\hline $\mathrm{EX} \lambda_{\max } / \mathrm{nm}$ & 257.4 & 257.0 & 257.0 \\
$\mathrm{INT}$ & 443.876 & 365.323 & 257.318 \\
$\mathrm{EM} \lambda_{\max } / \mathrm{nm}$ & 591.1 & 593.7 & 590.3 \\
$\mathrm{INT}$ & 163.527 & 440.298 & 792.875 \\
\hline
\end{tabular}

Table 4. XRD numbers of value of OTP-As (2:1).

\begin{tabular}{cccccc}
\hline No. & $2 \theta$ & $\mathrm{d} / \mathrm{nm}$ & Count & Relative Intensity & Half the height B \\
\hline 1 & 5.706 & 15.4747 & 222 & 6.1 & 0.334 \\
2 & 7.314 & 12.0762 & 130 & 3.6 & 0.259 \\
3 & 21.401 & 4.1486 & 3650 & 100.0 & 0.514 \\
4 & 24.049 & 3.6974 & 277 & 7.6 & 0.281 \\
\hline
\end{tabular}

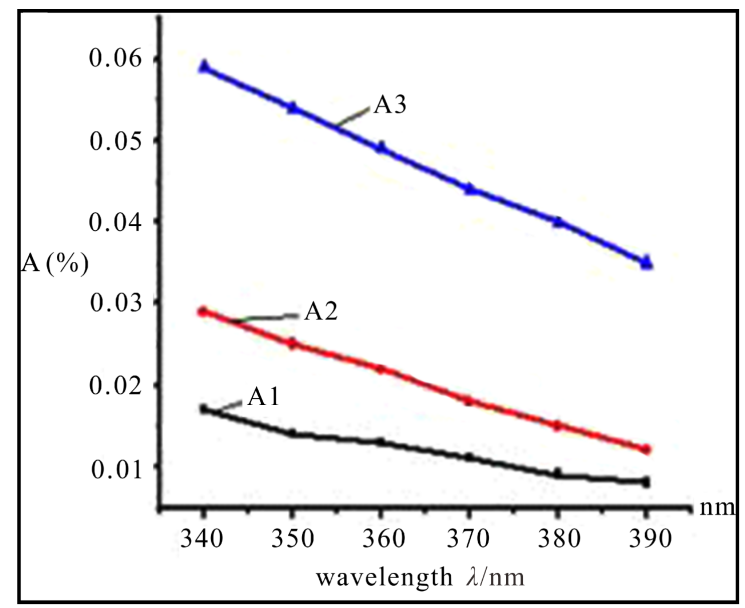

Figure 8. XRD spectrum OTP-As (2:1). 
ethanol solution. Figure 9 shows that absorbance of the same substance increases along with concentration and absorbance of OTP-As synthesized under the condition of $n(O T P): n\left(\mathrm{As}^{3+}\right)$ was $=2: 1$ increases along with the decrease of wavelength.

In Table 6, X stands for group of proton peaks. The whole spectrum indicates that in addition to the quite large mass peak shift of benzene ring, proton peaks of $\begin{gathered}b^{\prime} \\ \mathrm{CH}_{2}-\mathrm{CH}(\mathrm{OH}) \mathrm{CH}\end{gathered}$ were stronger than OTP-As, most of the rest were repeated display.

Comparison of ${ }^{1} \mathrm{H}-\mathrm{NMR}$ between OTP and OTP-As manifests that after OTP-polyol-complexed with $\mathrm{As}^{3+}$, ${ }^{1} \mathrm{H}-\mathrm{NMR}-\mathrm{OH}$ peaks in aromatic ring of Ph-OH shifted from 5.446 - 5.953 (quart) to 5.231 - 5.753 (quart); other -OH peaks shifted from $3.043(\mathrm{OH})$ to $3.116(\mathrm{OH})$. The obvious shift suggests that $\mathrm{As}^{3+}$ has already complexed with OTP and OTP-As was produced.

Table 5. Absorption photoelectron values of OTP.

\begin{tabular}{cccc}
\hline Wavelength $\lambda / \mathrm{nm}$ & $\mathrm{m}(\mathrm{A} 1)=0.0010 \mathrm{~g}$ & $\mathrm{~m}(\mathrm{~A} 2)=0.0020 \mathrm{~g}$ & $\mathrm{~m}(\mathrm{~A} 3)=0.0030 \mathrm{~g}$ \\
\hline 340 & 0.017 & 0.029 & 0.059 \\
350 & 0.014 & 0.025 & 0.054 \\
360 & 0.013 & 0.022 & 0.049 \\
370 & 0.011 & 0.018 & 0.044 \\
380 & 0.009 & 0.015 & 0.040 \\
390 & 0.008 & 0.012 & 0.035 \\
\hline
\end{tabular}

Table 6. ${ }^{1} \mathrm{H}-\mathrm{NMR}$ results of OTP-As and OTP.

\begin{tabular}{ll}
\multicolumn{1}{c}{ OTP $\delta$ x (peak) } & \multicolumn{1}{c}{ OTP-As $\delta$ x (peak) } \\
\hline 6.52 - 7.26 (multiplet) $\mathrm{Ph}-\mathrm{H}$ & $6.537-7.300$ (multiplet) $\mathrm{Ph}-\mathrm{H}$ \\
5.446 - 5.953 (quart) $\mathrm{Ph}-\mathrm{OH}$ & $5.231-5.753$ (quart) $\mathrm{Ph}-\mathrm{OH}$ \\
3.972 - 3.984 (doublet) $>\mathrm{CH}-\mathrm{O}-$ & $3.970-3.981$ (doublet) $>\mathrm{CH}-\mathrm{O}-$ \\
3.043 (singlet) (OH) & 3.116 (singlet) (OH) \\
2.486 (multiplet) $\mathrm{CH}-\mathrm{CH}(\mathrm{OH}) \mathrm{CH}-$ & 2.479 (multiplet) $\mathrm{CH}-\mathrm{CH}(\mathrm{OH}) \mathrm{CH}-$ \\
1.960 - 2.184 (doublet) $\mathrm{CH}-\mathrm{CH}(\mathrm{OH}) \mathrm{CH}$ & $1.959-2.184$ (doublet) $\mathrm{CH}-\mathrm{CH}(\mathrm{OH}) \mathrm{CH}$ \\
1.484 - 1.587 (doublet) $\mathrm{CH}$ & $1.483-1.586$ (doublet) $\mathrm{CH}$ \\
1.195 (quart) $\mathrm{CH}_{2}$ & 1.193 (quart) $\mathrm{CH}_{2}$ \\
0.783 (triplet) $\mathrm{CH}_{3}$ & 0.782 (triplet) $\mathrm{CH}_{3}$ \\
\hline
\end{tabular}

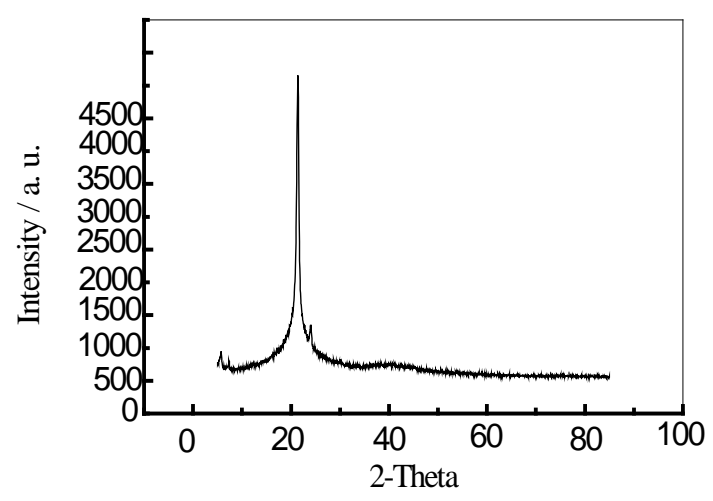

Figure 9. Photometric value of OTP-As (2:1). 


\section{Conclusion}

In ethanol solution, under the condition of $\mathrm{n}(\mathrm{OTP}): \mathrm{n}\left(\mathrm{As}^{3+}\right)=2: 1$, certain $\mathrm{pH}$, reaction temperature $40^{\circ} \mathrm{C}-45^{\circ} \mathrm{C}$, reaction time $15 \mathrm{~h}$, the target OTP-As was synthesized. OTP-As is ascertained as double-coordinated polycrystalline mixture by fluorescence analysis, spectrophotometry and $\mathrm{X}$ ray derivative technology. Fluorescence quantitative analysis can be used for detection of different complexes. There are still many free phenol-OH in OTP-As, which may have antibacterial, antiviral (such as influenza and AIDS virus), anti-cancer, cancer prevention and anti-aging effects.

\section{References}

[1] Li, H. and Liu, Y.M. (2004) Tea Polyphenols and Metal Compound Structure-Activity Relationship. Master Degree Thesis, Sichuan University, Chengdu.

[2] Bushman, J.L. (1998) Green Tea and Cancer in Human: A Review of Theliterature. Nutrition and Cancer, 31, 151-159. http://dx.doi.org/10.1080/01635589809514697

[3] Szoboszlai, N., Polgi, Z., Mihucz, V.G., et al. (2009) Recent Trends in Total Reflection X-Ray Fluorescence Spectrometry for Biological Applications. Analytica Chimica Acta, 633, 1-18. http://dx.doi.org/10.1016/j.aca.2008.11.009

[4] Valcárcel, M., Arce, L. and Ríos, A. (2001) Coupling Continuous Separation Techniques to Capillary Electrophoresis. Journal of Chromatography A, 924, 3-30. http://dx.doi.org/10.1016/S0021-9673(01)00898-6

[5] Stahl, W., van den Berg, H., Arthur, J., et al. (2002) Bioavailability and Metabolism. Molecular Aspects of Medicine, 23, 39-100. http://dx.doi.org/10.1016/S0098-2997(02)00016-X

[6] Schifferle, R.E. (2005) Nutrition and Periodontal Disease. Dental Clinics of North America, 49, 595-610. http://dx.doi.org/10.1016/j.cden.2005.03.008

[7] Salvador, A., Chisvert, A., Carre, A.S., et al. (2007) Analysis of Cosmetic Products. Publisher Elsevier, Amsterdam, 475-487.

[8] Russo, G.L. (2007) Ins and Outs of Dietary Phytochemicals in Cancer Chemoprevention. Biochemical Pharmacology, 74, 533-544. http://dx.doi.org/10.1016/j.bcp.2007.02.014

[9] De Groot, A. and Dommisse, R. (1995) Advantages of Long-Range-INEPT Measurements for Structure Determination of Catechin Esters. Bulletin of Magnetic Resonnance, 17, 242-243.

[10] Wang, S.X. and Wang, L.X. (2000) Characteristics of Oil-Soluble Tea Polyphenols and Application of. Tea Science and Technology, 3, 17-18.

[11] Zhou, W.F. (2007) Tea Polyphenol Selenium Complexes: Synthesis and Structure Characterization of. Fine Chemical Industry, 3, 248-260.

[12] Huang, H.N., Li, A.Z., Weng, L.N., et al. (2007) Tea Polyphenol Manganese Synthesis, Characterization and Complexation and Induction of Apoptosis in Tumor Cells. Chemical Journal of Chinese Universities, 6, 1072-1076.

[13] Yang, R.F., Zhang, C.S. and Hao, S.H. (2003) Medical Research on Nutrition of Trace Element Arsenic. Medicine, 9, 12-14.

[14] Xie, H.F. (2001) Arsenic on Human Diversity. Foreign Medical Health, 28, 265-269.

[15] Cao, R.Y., Qian, Z.Y. and Liu, J.J. (2003) The Treatment of Leukemia “Offbeat” Flower of Small Dose of Arsenic Treatment-APL. Chinese Prescription Medicine, 6, 72-73.

[16] An, Y. (2006) Arsenic Carcinogenesis Mechanism. Chinese Journal of Control of Endemic Diseases, 11, 271-274.

[17] Zhou, W.F. and He, Q.S. (2008) Irreversible Phase Transfer Method for the Synthesis of Tea Polyphenols and Spectra of Arsenic. Fine Chemical Industry, 4, 347-350.

[18] Mainardi, T., Kapoor, S. and Bielory, L. (2009) Complementary and Alternative Medicine Herbs, Phytochemical Sandvitamin Sand the Irimmuno Logic Effects. Journal of Allergy and Clinical Immunology, 123, 283-294. http://dx.doi.org/10.1016/j.jaci.2008.12.023

[19] Liska, D., Lyon, M. and Jones, D.S. (2006) Detoxification and Biotrans Formation Alimbalances Explore. Science and Healing, 2, 122-140.

[20] Kohlmeier, M. (2003) Minerals and Trace Elements Nutrient Metabolism. Academic Press, London, 643-768.

[21] Li, B.H., Wang, G.H., Jia, J.X., et al. (2002) Study of Spectro Fluorometric Determination of Race Germanium with Phenyl fluorine. Chemical Research and Application, 14, 242-244. 
Scientific Research Publishing (SCIRP) is one of the largest Open Access journal publishers. It is currently publishing more than 200 open access, online, peer-reviewed journals covering a wide range of academic disciplines. SCIRP serves the worldwide academic communities and contributes to the progress and application of science with its publication.

Other selected journals from SCIRP are listed as below. Submit your manuscript to us via either submit@scirp.org or Online Submission Portal.
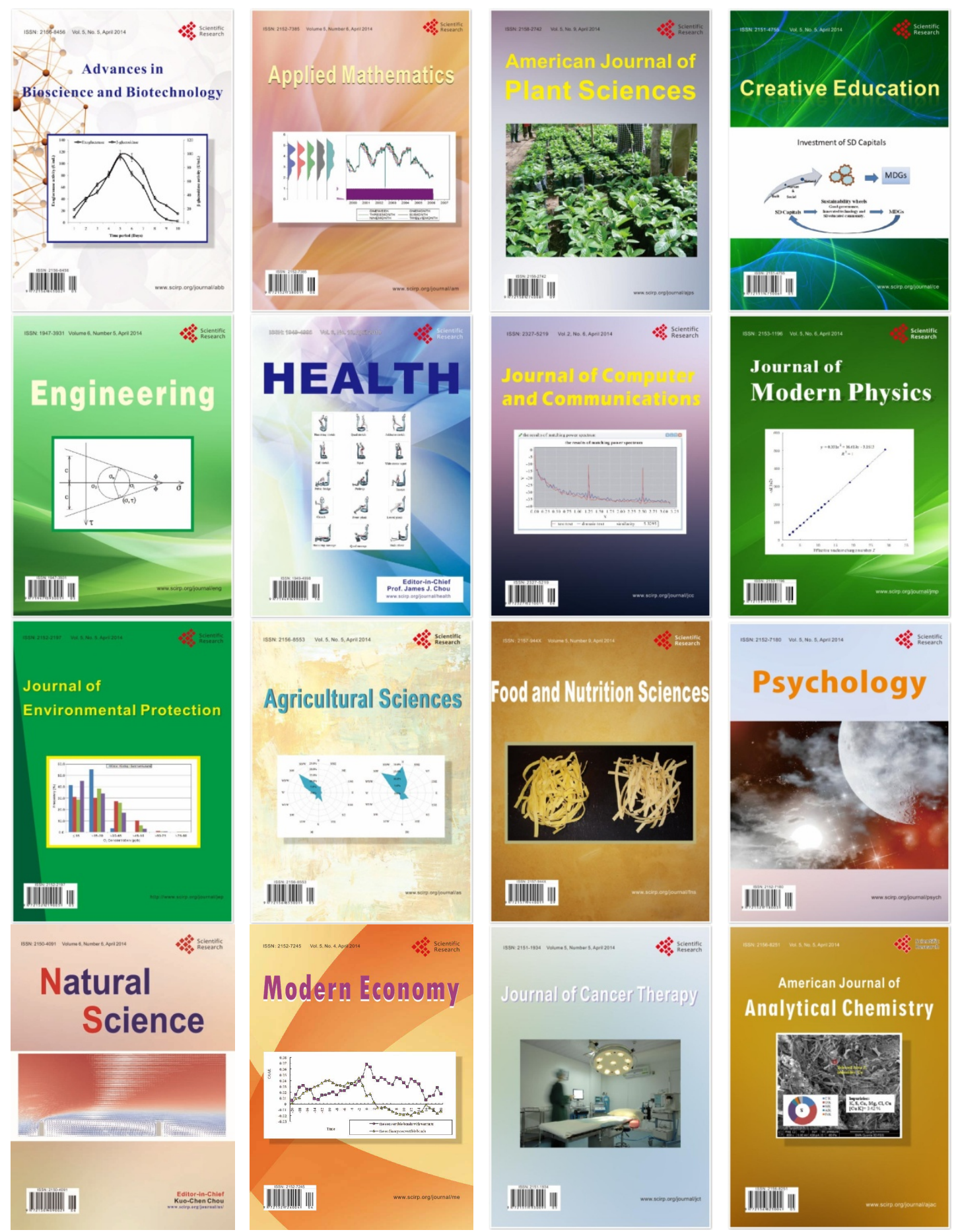